\title{
Multikulturalisme Tanpa Fondasi: Limitasi Pendekatan Legal-Formal dalam Mewujudkan Masyarakat Multikultural di Indonesia
}

\section{Nuruddin Al Akbar}

Institute for Multiculturalism and Pluralism Studies, Yogyakarta

\section{Listiana Asworo}

\section{Universitas Muhammadiyah Malang}

\section{INTISAR|}

Studi ini hendak melakukan pembacaan kritis terhadap strategi pemerintah Jokowi untuk membendung arus radikalisme di Indonesia dengan pendekatan legal formal sebagaimana yang nampak dari disahkannya Undang Undang tentang Ormas. Studi ini berargumen bahwa logika legal-formal tersebut tidak dapat dilepaskan dari ide multikulturalisme yang mensyaratkan dua komponen, yakni hadirnya negara transenden dan sense of public yang kuat di masyarakat. Mengambil perspektif struktural-fungsional, ketidakhadiran satu komponen saja dalam sebuah tatanan struktur, maka akan menyebabkan fungsi yang diharapkan tidak terwujud. Studi ini sendiri secara spesifik mengambil FPI sebagai obyek studi dengan alasan sepak terjang FPI selama ini telah menabrak batas toleransi yang diizinkan dalam skema multikulturalisme. FPI tidak hanya bergerak di level ide, tetapi juga melakukan kekerasan fisik terhadap kelompok lain yang dianggap tidak sejalan dengan visinya. Studi ini menunjukkan bahwa eksistensi FPI justru mendapat dukungan dari elemen kepolisian dan TNI yang seharusnya menjadi ujung tombak negara dalam menegakkan hukum, termasuk juga dukungan sebagian masyarakat yang cukup besar pada FPI. Dukungan tersebut menjadi bukti adanya problem mendasar pada ide multikulturalisme di Indonesia, dimana prasyarat negara transendental dan sense of public yang kuat yang seharusnya menjadi basis utama penopang bekerjanya multikulturalisme ternyata tidak hadir dalam konteks Indonesia.

\section{KATA KUNCI}

Front Pembela Islam; multikulturalisme; negara transeden, sense of public; struktural-fungsional

\section{Korespodensi:}

IMPULSE Yogyakarta, Jalan Gandok Baru, Condongcatur, Manggung, Caturtunggal, Kec. Depok, Kabupaten Sleman, Daerah Istimewa Yogyakarta 5528.

Email: nuruddin.alakbar@gmail.com; listianaasworo@umm.ac.id 


\section{Pendahulluan}

$\mathrm{P}$ ada tahun 2017, Pemerintahan Jokowi-Jusuf Kalla mengeluarkan Perppu Ormas (Peraturan Pemerintah Pengganti Undang-Undang Nomor 2 Tahun 2017) sebagai pengganti UU Ormas sebelumnya (Undang-Undang Nomor 17 Tahun 2013) yang dianggap tidak mampu menjaga Indonesia dari ancaman radikalisme. Perppu No. 2 Tahun 2017 yang dikeluarkan rezim Jokowi tersebut memberi landasan hukum bagi pemerintah untuk membubarkan ormas yang dianggap bertentangan dengan Pancasila. Dalam UU ormas yang lama, definisi bertentangan dengan Pancasila memang sangat spesifik merujuk pada ideologi atheisme, komunisme, dan Marxime-Leninisme yang notebene digunakan untuk melarang organisasi PKI dan organisasi yang berafiliasi dengan kelompok kiri (Ahmad, 2017). Dalam Perppu Ormas ini, selain atheisme dan komunisme ditambahkan frasa baru “...atau paham lain yang bertujuan mengganti/mengubah Pancasila dan Undang-Undang Dasar Tahun 1945” (Erdianto, 2017).

Dengan penambahan frasa tersebut, maka pemerintah dapat mengambil sikap yang lebih keras terhadap kelompok "radikal". Kelompok "radikal" yang dimaksud notabane diarahkan pada kalangan Islam "non Mainstream", dalam hal ini selain Muhammadiyah atau NU (Ali, 2011; Azra, 2013: 70; Bruinessen, 2013: 42). ${ }^{1}$ Pasca reformasi, kelompok radikal ini mulai menunjukkan perkembangan yang signifikan di Indonesia seiring tumbangnya rezim otoritarian Jendral Soeharto (Turmudi \& Sihbudi, 2005: 287). Nama-nama ormas seperti HTI, FPI, Jamaah Anshorut Tauhid, Majelis Mujahidin Indonesia, hingga Jamaah Islamiyah merupakan sederet nama ormas Islam yang diasosiasikan sebagai bagian dari gerakan "radikal"2 yang dimaksud (Umam, 2015: 92; Wahab, 2014: 105; Widyantini, 2016: 306).

Meskipun langkah pemerintah tersebut menuai kontroversi karena penambahan frasa dalam Perppu Ormas tersebut dinilai sebagian kalangan mengandung ambiguitas dan potensial dipergunakan untuk membungkam oposisi secara umum (Qurtuby, 2017), akan tetapi dukungan terhadap Perppu tersebut juga tidaklah sedikit (Ibrahim, 2017; Fabian Januaris Kuwado, 2017; Prihatin, Mashabi, \& Mardani, 2017; Putri, 2017). ${ }^{3}$ Bahkan dengan dukungan sejumlah partai politik di DPR, rezim Jokowi berhasil mendorong Perppu Ormas tersebut menjadi Undang-Undang yang memiliki kekuatan hukum yang lebih kuat karena telah mendapat persetujuan dari DPR (Sasongko, 2017).

Narasi yang diciptakan rezim tentang kedaruratan keadaan yang harus ditindaklanjuti dengan langkah yang lebih keras memang berhasil mengambil hati sebagaian masyarakat untuk mendukung Perppu ormas tersebut (Fabian Januarius Kuwado, 2017). Euforia terhadap keluarnya perppu tersebut bahkan tergambar dari kartun yangdimuat dalam The New York Times (Heng, 2017). Dalam ilustrasi tersebut, Jokowi digambarkan sedang memegang semprotan anti hama untuk menyerang tanaman "monster" (digambarkan semacam tanaman venus pemakan daging) yang tumbuh subur di lahan bernama Indonesia. Nampaknya sang ilustrator membayangkan Perppu Ormas sebagai senjata ampuh Jokowi untuk "membasmi hama" tersebut, yang tidak lain disebut oleh sang ilustrator sebagai kalangan "Islam Radikal". Gambaran The New York Times tersebut sejatinya menggambarkan imaji 
pada sebagian kalangan yang mendukung dikeluarkannya perppu tersebut yang berharap dengan adanya perppu tersebut rezim Jokowi akan mampu menangkal arus radikalisme di Indonesia.

Seakan ingin memberikan sinyal bahwa "semprotan anti hama" tersebut (UU Ormas) bukan pajangan belaka, rezim Jokowi langsung mengambil langkah untuk membubarkan HTI dengan alasan organisasi tersebut terindikasi mengembangkan paham anti-Pancasila (Movanita, 2017). Pemerintah tidak kesulitan untuk membubarkan HTI dalam arti legal formal, yakni mencabut izin legalitas organisasi tersebut di Kemenkumham karena UU Ormas baru memberi ruang bagi pemerintah untuk mencabut izin ormas tanpa harus melalui jalur pengadilan. Walaupun dalam UU Ormas baru tersebut organisasi yang dicabut izinnya dapat menuntut ke pengadilan jika tidak terima dengan keputusan pemerintah (Jordan, 2017).

Melihat kebijakan rezim Jokowi di atas, secara sepintas terlihat bahwa langkah menerbitkan perppu baru (yang kemudian menjadi UU Ormas) dan kebijakan pembubaran HTI tidak lama setelah dikeluarkannya perpu tersebut, memperlihatkan asumsi bahwa radikalisme dapat ditangkal melalui strategi yang sifatnya legal formal (Erwanti, 2018). ${ }^{4}$ Dengan kata lain, berbasiskan UU sebagai legitimasi hukum dan birokrasi, termasuk aparat keamanan sebagai ujung tombak, dibayangkan pemerintah dapat menyelesaikan perkara dengan mudah. Studi ini memiliki preposisi yang berbeda dengan cara pandang optimistik tersebut, dan sebaliknya lebih berpandangan pesimistik dalam melihat strategi legal formal yang ditempuh rezim Jokowi.

Memang benar eksistensi ormas radikal semacam HTI bisa dicabut izinnya walaupun ini hanyalah sebuah "kasus khusus", ${ }^{5}$ akan tetapi tidak berarti strategi semacam ini bisa menyelesaikan problem radikalisme di Indonesia. Jauh sebelum solusi rezim Jokowi ini coba diaplikasikan secara nyata, Hasyim Muzadi, salah satu intelektual Nahdlatul Ulama pernah berkata, "Nanti Front Pembela Islam pada hari Jumat (dibubarkan), Hari Minggu bisa (berganti nama) Front Pembela Indonesia" (Rimawan, 2014). Secara khusus, Muzadi memang menyebut FPI tetapi secara umum ungkapan ini bisa diterapkan untuk melihat semua ormas radikal di Indonesia (NU Online, 2018). ${ }^{6}$ Artinya, solusi pembubaran semacam ini hanya bersifat artifisial dan tidak akan menyentuh ke jantung persoalan.

Kalangan optimistik mungkin akan mencoba berkelit dengan menyatakan bahwa proses "pembasmian hama" barulah memasuki tahap awal. Memang pada fase awal ini dimulai dengan pencabutan izin eksistensi organisasi mereka secara hukum. Tetapi fase awal ini akan berlanjut dengan fase-fase selanjutnya yang lebih mengena, seperti upaya penyadaran terhadap anggota ormas radikal tersebut (Zulfikar, 2017), ${ }^{7}$ termasuk juga akan mempermudah kerja aparat keamanan untuk menindak setiap anggota ormas radikal yang melakukan berbagai aktivitas melawan hukum (Movanita, 2017). Argumen semacam ini mungkin terkesan logis dalam tataran ide, tetapi dalam praktek di lapangan akan sangat sulit diwujudkan.

Adanya perbedaan di level ide dengan penerapan di lapangan inilah yang menjadi titik tolak studi ini mengambil posisi pesimis dalam memadang strategi legal formal sebagai upaya mengatasi masalah "radikalisme" di Indonesia. Hipotesis yang dipegang dalam studi ini ialah penerapan di 
lapangan tidaklah semudah yang dibayangkan dalam level ide karena ada problem yang sifatnya mendasar dalam logika legal formal tersebut. Problem mendasar inilah yang menyebabkan solusi legal formal itu layaknya sebuah pidato yang begitu memukau pendengarnya, tetapi tidak dapat direalisasikan dalam dunia nyata.

Studi ini berupaya menjelaskan adanya problem mendasar pada strategi menghadang "radikalisme" bersenjatakan pendekatan legal formal dari rezim Jokowi. Di mana problem mendasar ini berkaitan dengan ide multikulturalisme yang menjadi ruh atau spirit dari kebijakan anti-radikalisme. Studi ini memegang hipotesis bahwa cara pandang multikultural yang dipegang rezim ataupun sejumlah akademisi yang sejalan dengan rezim memiliki kekeliruan karena tidak peka konteks Indonesia sehingga begitu percaya dengan pendekatan legal formal. Padahal pendekatan legal formal dalam mulitukturalisme hanya dapat bekerja jika sejumlah prasyarat mendasar telah hadir di wilayah tempat dilaksanakannya kebijakan multikulturalisme tersebut. Sementara studi ini meyakini bahwa prasyarat tersebut tidak hadir dalam konteks Indonesia sehingga tidak memungkinkan kebijakan multikultural tersebut dapat bekerja dalam konteks Indonesia, atau kalaupun kebijakan tersebut mampu berjalan maka tidak lebih dalam wujud yang artifisal.

Studi ini sendiri secara khusus melakukan kajian pada FPI yang berfungsi untuk memperlihatkan konteks, bahwa secara faktual adanya problem yang sifatnya fundamental sehingga menghalangi bekerjanya solusi legal formal anti radikalisme dari rezim Jokowi yang sejatinya dibuat untuk menjaga tatanan plural (kebhinekaan) Indonesia dari rongrongan kalangan "radikal". FPI sendiri dipilih karena sejatinya berbeda dengan HTI. Benar bahwa HTI mengusung ide yang lebih besar, yakni mengganti konsep negara bangsa dengan ide pemerintahan global seperti Khilafah, tetapi mereka hanya bergerak di level ide saja. Berbeda dengan FPI yang bergerak dengan menggunakan kekerasan sebagai mode operasi mereka dalam berhadapan dengan kelompok lain yang dipandang tidak sesuai dengan visi misinya. Ini adalah sebuah realitas yang telah menabrak batas toleransi perbedaan yang diizinkan dalam logika multikulturalisme (Express, 2016). ${ }^{8}$

\section{Menyelami Multikulturalisme Secara Kontekstual}

Studi ini mengambil posisi yang pesimistik dalam memandang kebijakan anti-radikalisme dari rezim Jokowi yang berbasis pendekatan legal formal. Posisi pesimistik ini diambil berdasarkan hipotesis bahwa kebijakan tersebut yang berakar dari logika multikulturalisme gagal dalam melihat situasi yang ada di Indonesia atau tidak kontekstual sehingga tidak menyadari bahwa ada bagian yang masih kosong (missing link) dalam kebijakan tersebut. Bagian yang kosong itu sendiri memiliki fungsi yang vital untuk memastikan kebijakan tersebut dapat dijalankan dengan baik. Hal ini menjadi penting untuk mengukur apakah kebijakan legal-formal yang ditempuh mampu secara efektif untuk mereduksi kelompok-kelompok yang digolongkan sebagai "radikal".

Guna memahami apa yang bermasalah dalam logika rezim Jokowi dan kalangan lain yang sepemahaman dengannya, maka perlu dilacak terlebih dahulu fondasi dari kebijakan rezim Jokowi 
tersebut yang notabene berakar dari perspektif multikulturalisme. Gagasan multikulturalisme inilah yang kemudian perlu didekati dengan kacamata struktural-fungsional untuk melihat sejauh mana gagasan tersebut bisa dihadirkan dalam konteks Indonesia. Kacamata struktural-fungsional di sini sebagai alat untuk membantu kita memahami gagasan multikulturalisme secara kontekstual, bukan semata pedoman tektual saja tetapi melupakan realitas yang ada di sekelilingnya sehingga jatuh pada dogmatisme (Massier, 2008: 227). ${ }^{9}$ Lebih jauh dogmatisme yang dimaksud justru semakin menjauhkan kalangan yang meyakininya dari melihat kenyataan secara lebih kritis dan pada akhirnya justru terus menerus berkutat pada tawaran solusi yang keliru karena berpijak pada asumsi yang keliru pula.

Pertama, marilah kita tinjau secara lebih kritis mengenai definisi multikulturalisme itu sendiri untuk melihat keterkaitannya dengan strategi anti-radikalisme dari rezim Jokowi dengan Perppu Ormasnya. Multikulturalisme sendiri memang merupakan istilah yang hingga saat ini masih menjadi perbincangan di kalangan akademisi (Fortier, 2008: viii; Jupp, 2011: 41). Dengan kata lain, istilah multikulturalisme tidak hanya menyimpan satu definisi yang tunggal melainkan pluralitas makna. Bahkan dengan alasan keragaman makna, multikulturalisme itulah oleh sebagaian kalangan menyamakannya dengan istilah lain yakni diversity (keragaman) atau lebih spesifik lagi cultural diversity atau keragaman kultural (Olofinjana, 2014: 75-76). Penyamaan makna itu tidak sepenuhnya salah karena multikulturalisme memang berkaitan erat dengan masalah keragaman, pluralitas, atau lawan dari monokultur (Kamran, 2007: 93).

Bekker \& Leildé (2003) memberikan sedikit “pencerahan” untuk memahami fenomena multikulturalisme ini berdasarkan sistem kategorisasinya. Menurut Bekker dan Leilde (2003), setidaknya ada tiga makna multikulturalisme yang berbeda, walaupun esensinya tetap membicarakan mengenai masalah keragaman. Pertama, multikulturalisme sebagai deskripsi. Arti dari deskripsi ini adalah multikulturalisme menggambarkan adanya realitas empiris berupa masyarakat yang plural, masyarakat yang berisikan aneka keragaman kultural. Kedua, multikulturalisme sebagai doktrin/ ideologi. Maksud dari ideologi di sini ialah multikulturalisme tidak hanya sebatas mendeskripsikan realitas yang ada, tetapi juga semacam cara berfikir atau sebuah paradigma yang percaya atau meyakini bahwa beragam kultur bukannya satu kultur (monokultur) dapat hidup berdampingan secara damai dalam sebuah negara. Dengan kata lain, paradigma ini juga memiliki implikasi politis, yakni mendorong atau melegitimasi inkorporasi keragaman budaya dalam tatanan masyarakat luas. Ketiga, multikulturalisme sebagai kebijakan publik. Kebijakan publik disini lebih bermakana bahwa multikulturalisme terkait erat dengan urusan teknis, yakni bagaimana memastikan terciptanya sebuah kesatuan nasional di tengah keberagaman tersebut.

Dengan kata lain makna multikulturalisme di sini sifatnya sangat praxis, terkait dengan kebijakan strategis yang akan diambil oleh pemerintah untuk menegakkan sebuah tatanan di tengah perbedaan budaya (Leilde, 2003: 119; Meien, 2004: 3). Berdasar pada tiga makna, di atas dapat dikatakan bahwa makna multikulturalisme sebagai kebijakan publik itulah yang terkait erat dengan kebijakan antiradikalisme dari rezim Jokowi. Kebijakan anti-radikalisme adalah cara yang dipandang strategis oleh 
rezim Jokowi untuk menegakkan sebuah tatanan yang menjamin perbedaan budaya dapat hidup berdampingan dalam sebuah bingkai negara bangsa bernama NKRI.

Menempatkan multikulturalisme sebagai sebuah kebijakan publik memiliki implikasi politis yang sangat besar di mana membayangkan peran negara yang sentral dalam hal ini. Sebagaimana dinyatakan oleh Kim, multikulturalisme tidak lagi dipahami sebagai preexisting condition alias kondisi yang telah ada sebelumnya tetapi bagaimana kondisi mulikultural (keberagaman) tersebut tercipta dengan tangan dingin negara melalui kebijakannya, baik untuk mereproduksi, mentransformasi, bahkan mendekonstruksi keberagaman tersebut (Goh, 2016: 217). Intinya eksistensi keragaman di tengah masyarakat hanya dapat dipertahankan atau dikreasi jika ada campur tangan negara yang memihak, dalam artian negara memihak ideologi multikulturalisme.

Terkait dengan posisi negara yang sangat sentral dalam diskursus multikulturalisme, Bhikhu Parekh (1999) memberikan sejumlah penekanan penting tentang posisi negara ini, terkhusus mengenai prasyarat yang harus dipenuhi oleh sebuah negara jika ingin kebijakan multikulturalismenya dapat diterapkan dengan baik. Bagi Parekh (1999) prasyarat fundamental yang harus dimiliki oleh sebuah negara multikultural adalah mampu mentransformasikan dirinya menjadi culturally neutral and socially transcendental state. Di mana negara harus bertindak secara imparsial tidak mengutamakan salah satu golongan tetapi semua golongan yang berbeda. Termasuk pula negara harus mampu merancang sistem disiplin diri yang memungkinkan tidak ada golongan tertentu -terlebih golongan mayoritas- untuk masuk dan mempergunakan negara sesuai kehendak mereka (menerapkan sistem monokultur). Parekh (1999) sendiri sejatinya tidak menunjuk sebuah negara ideal untuk menjadi contoh multikulturalisme tetapi sedang berbicara mengenai kondisi India yang dianggapnya tidak ideal dalam menerapkan multikulturalisme. Tetapi justru dari pemaparan tentang contoh negara yang tidak ideal tersebut, yakni India, kita dapat memetik abstraksi penting bahwa setidaknya mestilah hadir sebuah entitas culturally neutral and socially transcendental state jika ingin multikulturalisme berjalan dengan baik.

Selain negara, Parekh (1999) juga menegaskan prasyarat lain yang tidak kalah pentingnya yakni sense of public. Tentu sense of public ini tidak bisa dilepaskan dari gagasan citizenship yang membayangkan adanya sebuah kesadaran (konsientisasi) -atau dalam bahasa Parekh adalah sense of belonging- pada diri individu dan kelompok kultural yang ada akan keterikatan mereka pada satu political community (yang dimaksud lebih kepada kepatuhan pada rule of law dalam sebuah negara bangsa), sehingga paham hak dan kewajiban mereka (Bolo, 2006). Dapat dikatakan kesadaran akan hak dan kewajiban tersebut salah satunya temanifestasi dari ada tidaknya "sense of public" pada diri individu atau kelompok kultural tertentu. Sense of public sendiri terkait dengan kemampuan diri untuk memposisikan dirinya sebagai warga negara yang memiliki loyalitas tersendiri pada political community tersebut dan sadar diri untuk tidak melakukan tindakan yang membahayakan eksistensinya. Perlu digarisbawahi disini bahwa komitmen terhadap political community tidak berarti seorang atau anggota kelompok kebudayaan tertentu tidak boleh mengkritisi pemerintah atau 
menuntut perubahan. Bagi Parekh itu sah-sah saja, karena lebih terkait dengan pembenanan sistem (format political community) bukan kepada penghancuran sistem (rule oflaw) itu sendiri (Bolo, 2006).

Bahkan Parekh menyebutkan bahkan dalam konteks masyarakat multikultural tidak bisa negara memaksa ada satu bentuk kebudayaan yang memang tidak menginginkan dirinya berwawasan multikultur dalam artian tidak menerima keragaman dari kelompok lain- karena jika paksaan dilakukan maka sama saja negara terjatuh dalam praktek penyeragaman itu sendiri. ${ }^{10}$ Tetapi ada batasan yang tidak bisa dilanggar dalam multikulturalisme ini yakni kelompok anti multikultur tersebut memang dapat mempertahankan pilihannya tetapi dengan catatan mereka tetap mempertahankan sense of belonging mereka kepada satu political community. Dengan kata lain mereka boleh tidak suka dengan gaya hidup suatu budaya tertentu, hal ini masih ditoleransi dalam masyrakat multikultur. Tetapi jika menabrak aturan dari political community tersebut, misalnya main hakim sendiri terhadap kelompok yang berbeda maka hal ini tidak dapat ditolelir lagi.

Penjelasan Parekh mengenai sejumlah prasyarat multikulturalisme tersebut dipahami secara lebih abstraktif dengan meminjam pendekatan struktural fungsional. Pendekatan struktural fungsional sendiri lekat dengan dua nama akademisi kenamaan yakni Talcott Parson dan Neil Smelser. Dalam upaya memahami masyarakat, mereka membuat sebuah "model" yang menarik untuk menggambarkan masyarakat layaknya organisme hidup (Newman, 2010: 18). Seperti jantung, hati, paru, ginjal, usus, dan berbagai organ lainnya yang membentuk satu kesatuan utuh yang memungkinkan sang manusia itu dapat hidup dan beraktivitas. Tidak bekerjanya satu komponen organ saja akan menyebabkan seseorang kesulitan menjalankan aktivitasnya (Newman, 2010). Bagi Parsons dan Smelser, sebagaimana organisme hidup ditopang dengan jaringan organ tersebut, masyarakat juga dapat hidup jika semua elemen-elemen struktur masyarakat bekerja bersama-sama membentuk satu kesatuan utuh (Harris, 2001: 515). ${ }^{11}$

Jika perspektif struktural fungsional tersebut dipakai untuk membaca multikulturalisme sebagaimana dinyatakan oleh Parekh, maka akan ditemukan sebuah logika dasar bahwa ide citizenship (khususnya soal sense of public) dan neutral and transendental state merupakan komponen-komponen penting penyusun multikulturalisme. Jika komponen-komponen tersebut tidak bekerja atau hilang maka bisa diprediksikan bahwa multikulturalisme juga tidak akan eksis. Atau jika dikaitkan dengan kebijakan pro multikulturalisme yang dibuat oleh rezim Jokowi maka bisa diasumsikan bahwa kebijakan tersebut juga tidak akan bekerja secara efektif.

Kedua, setelah meninjau secara kritis apa itu multikulturalisme, termasuk prasyarat yang dibutuhkan untuk menopang eksistensi masyarakat multikultural dan bagaimana melihat multikulturisme dari perpsektif struktural fungsional, marilah kita beranjak pada upaya mencermati konteks Indonesia, apakah prasyarat yang dibutuhkan multikulturalisme tersebut sudah hadir ataukah belum. Dalam hal ini adalah efektifitas kebijakan multikulturalisme itu sendiri dan juga masa depan masyarakat multikultur (atau bisa juga disebut kebhinekaan) yang ingin dilindungi oleh rezim Jokowi dari "ancaman radikalisme agama". Perlu ditegaskan tinjauan pada bagian ini sifatnya lebih ke arah teoritik, 
belum masuk secara spesifik pada FPI. Tinjauan ini lebih dimaksudkan untuk memperkokoh hipotesis paper ini yang mengasumsikan prasyarat yang dibutuhkan untuk menegakkan multikulturalisme di Indonesia sangat lemah sehingga wajar jika paper ini kemudian mengambil sikap "pesimistis" dalam melihat kebijakan rezim Jokowi yang notabene berbasis legal formal.

Pertama, apakah dalam konteks Indonesia telah hadir neutral and transendental state? Sebagaimana dengan India yang dianggap Parekh (1999) merupakan contoh negara yang tidak ideal dalam menerapkan multikulturalisme karena negara tidak imun dari "rongrongan" kalangan mayoritas yang ingin melakukan dominasi kekuasaan - penyeragaman sosial budaya- di India, kasus Indonesia juga menunjukkan kecenderungan yang hampir sama. Kesamaan disini bahkan dalam taraf yang lebih "akut" karena sebagai muncul fenomena floating state (Nordholt \& Klinken, 2007: 4). Fenomena ini memiliki kemiripan dengan diistilahkan state qua state, yakni wujud negara yang memiliki otonomi dari kehendak rakyatnya. Ia bekerja menuruti kehendaknya sendiri (Anderson, 1983). Floating state disini memiliki makna yang berbeda dengan apa yang dibayangkan Lay (2012). Bagi Lay (2012), floating state merujuk pada konsepsi negara yang tidak punya akar, dimana pada level lokal logika lokalitas (yang seringkali berbeda dengan logika negara) itulah yang bekerja. Sehingga secara de facto sebenarnya negara dalam keadaan rapuh (Lay, 2012). ${ }^{12}$

Sementara floating state yang dimaksud dalam paper ini adalah negara memang tidak memiliki akar. Tetapi dengan kondisi floating tersebut, negara tidak terikat pada akar, sehingga bebas memiliki kehendak sendiri. Faktanya, logika floating inilah yang terjadi di Indonesia sejak era kolonial. Negara tidak pernah menyerap aspirasi masyarakat, tetapi berjalan sesuai kehendaknya sendiri (Haris, 2006: 87). Anderson sendiri secara khusus menyoroti negara era Orde baru yang dianggapnya memiliki wujud serupa dengan era kolonial (Anderson, 1983).

Logika floating ini atau dalam istilah Anderson state qua state berkebalikan dengan logika negara bangsa di Eropa yang berposisi sebagai negara penjaga malam. Arti penting dari penjaga malam ialah posisinya netral dan transendal. Negara tidak memihak salah satu golongan tetapi berfungsi menjaga order, ketertiban, keamanan dalam mesyarakat tersebut. Tidak ada kehendak otonom negara dalam artian negara merangkap fungsi selain menjaga (guard) tetapi juga memerintah (rule) masyarakat (Elson, 2001). ${ }^{13}$

Satu hal yang patut juga untuk disinggung disini adalah imaji kita tentang negara. Dalam konteks kolonial dan orde baru yang dilukiskan Anderson negara layaknya entitas tunggal dengan satu kehendak tunggal yang otonom. Akan tetapi kajian-kajian akademisi lain pasca Anderson menemukan bahwa di dalam tubuh negara juga terdiri dari berbagai kesadaran yang otonom, yang berarti ada pluralitas kehendak (Emmerson, 1983). ${ }^{14}$ Pluralitas kehendak ini terjadi karena di dalam negara tersebut ada berbagai kubu elit yang masing-masingnya memeiliki kepentingan sendiri.

Pluralitas kehendak ini semakin meluas pasca tumbangnya Orde Baru. Di tingkat lokal, negara (dalam konteks lokal) juga memiliki kehendak sendiri yang berlainan pusat (Jawa Pos, 2016). ${ }^{15}$ Jamak pula kita dengarkan pemberitaan mengenai instansi yang tidak harmonis menangani suatu perkara 
yang seharusnya dibutuhkan kerjasama di antara mereka (Sahrasad, 2009). ${ }^{16}$ Ini merupakan contoh bagaimana negara itupun tidak berkesadaran tunggal tetapi plural.

Dalam kaitannya dengan multikulturalisme -meminjam kacamata struktural fungsional-, negara dapat diposisikan sebagai komponen penting dari sistem yang lebih besar yakni bagian dari satu kesatuan sistem (penopang) bekerjanya sistem multikulturalisme. Dalam konteks multikulturalisme, dipersyaratkan adanya harmoni pada setiap komponen di dalam negara untuk memastikan bekerjanya multikulturalisme. Sehingga satu daerah atau satu instansi (kepolisian misalnya) tidak boleh bersuara lain, semua harus satu kata untuk mendukung multikulturalisme. Tidak ada ruang untuk berbeda dalam konteks ini. Karena jika satu instansi berbeda (ibaratnya satu komponen saja tidak bekerja) maka bisa diprediksikan multikulturalisme tidak akan bekerja (Emmerson, 1983).

Setelah memahami bahwa ada dalam konteks Indonesia ada problem besar dalam konteks wujud dan nalar negara yang tidak ideal bagi penerapan kebijakan multikulturalisme sekarang marilah kita beranjak untuk memahami secara lebih kritis adakah sense of public dalam tubuh masyarakat Indonesia? Jika kembali mengacu pada Parekh (1999) bahwa sense of belonging erat kaitannya dengan ide citizenship. Dimana terjadi keradaran diri individu (atau kelompok kultural tertentu) pada satu political community. Istilah komitmen pada Political community inilah yang perlu digarisbawahi karena tanpa komitmen pada satu entitas baru bernama political community atau dapat dinyatakan sebagai negara (lebih tepatnya rule of law dalam negara), maka mustahil multikulturalisme dapat ditegakkan dengan baik. Parekh (1999) sendiri secara jeli menyebut adanya berbedaan mendasar antara komitmen pada political community dengan komitmen pada "shared cultural, ethnic and other characteristics". Karena bagi Parekh (1999) komitmen pada hal-hal tersebut "for a multicultural society is too diverse for that". Artinya sangat sulit menemukan satu benang merah yang bisa dipijaki bersama jika mengandalkan keterikatan pada satu komitmen entis atau kultural tertentu yang tentunya sangat berlainan satu dengan yang lainnya.

Ketika narasi kecil itulah yang berkembang di Indonesia bukan narasi besar maka akan sulit muncul sense of public sebaagimana yang diharapkan akan muncul oleh Parekh. Sebagai ilustrasi kecil saja, dalam tradisi kultural masyarakat ketika akan mengadakan acara hajatan (resepsi/selamatan) atau acara kematian seringkali memblokade fasilitas publik yang seharusnya dipakai oleh bersama, misal jalan raya (Tribunnews.com, 2018).

Padahal dalam bayangan sense of public semua pihak -termasuk pihak yang menyelenggarakan hajatan tersebut misalnya- harus tahu diri dimana akan melaksanakan hajatan. Dalam konsepsi citizenship, rule of law ini menjadi sesuatu yang ditegakkan bersama oleh anggotanya. Sehingga misalnya kalau mereka memang harus menggunakan jalan tersebut untuk hajatan atau acara kematian, mereka harus tahu diri dengan membuat rekayasa jalan sedemikan rupa yang tidak menyulitkan orang lain untuk melewati jalan tersebut.

Berdasar ilustrasi di atas dapat kita pahami bahwa potensi dominatif sangat mungkin muncul jika tidak ada komitmen bersama pada political community. Persoalannya, jika mengacu pada 
temuan Santoso (2018), ada problem besar dalam masyarakat Indonesia di mana logika narasi kecil yang lebih dominan. Jika itu yang terjadi, maka tentunya akan semakin menghalangi terciptanya multikulturalisme di Indonesia karena merujuk kembali pada konsepsi struktural fungsional tidak bekerjanya satu komponen saja mengakibatkan sistem tidak akan berfungsi optimal. Padahal yang bermasalah dalam konteks multikulturalisme di Indonesia adalah sense of public yang sangat kruisal bagi tegaknya multikulturalisme di negeri yang mengaku menjunjung kebhinekaan ini.

\section{Eksistensi FPI: Perselingkuhan Negara dan Kelompok Vigilante}

Dalam artikel ini, FPI diposisikan sebagai kelompok vigilante. Adapun vigilante memiliki pengertian yang sama dengan dengan main hakim sendiri, atau dalam definisi lain upaya kelompok masyarakat sipil yang berupaya menegakkan hukum dengan melawan hukum itu sendiri (Lane, 1976; Silaen, 2013). FPI sendiri diposisikan sebagai ormas yang secara diametral bertentangan dengan spirit multikulturalisme yang menghendaki tiadanya dominasi kultur tertentu dalam sebuah ruang publik. Apakah langkah legal formal seperti yang diupayakan rezim Jokowi dengan UU ormasnya mampu menjaga netralitas ruang publik tersebut? Telaah FPI pada bagian ini memiliki misi untuk menunjukkan realitas bahwa eksistensi FPI sangat terkait dengan adanya problem pada komponenkomponan yang dibutuhkan bagi sistem multikulturalisme untuk eksis. Sehingga diharapkan dengan melakukan analisa pada FPI menjadi salah satu bukti empiris untuk menunjukkan missing link fondasi multikulturalisme di Indonesia. Sehingga tidak bisa dihindari pembahasan pada bagian ini akan banyak menyinggung soal ide transendental dan neutral state maupun gagasan tentang sense of public dan relasinya dengan FPI.

Merujuk pada temuan Ichwan, FPI merupakan pionir "gerakan Islam radikal" yang melakukan aksi vigilantis terhadap tempat-tempat maksiat dan terlibat dalam sejumlah demonstrasi yang bernuansa kekerasan (Ichwan, 2013:68). FPI mampu melaksanakan aksi vigilante tersebut dalam sebuah ruang publik yang semestinya mendapatkan resistensi dari banyak pihak termasuk aparat keamanan -karena aksi melawan hukumnya-. Faktanya rintangan tersebut seakan dengan mudah ditembus oleh FPI yang hingga kini selain menjadi pionir masih dapat disebut sebagai organisasi keagamaan yang dikenal dengan aksi-aksi (Tempo.co, 2018). Telaah kritis pada kemampuan FPI melakukan aksi vigilantis tersebut akan mengungkap adanya problem besar pada ranah negara yang gagal menghadirkan dirinya sebagai transendental dan neutral state.

Kekhasan organisasi "radikal" ini dapat dilacak hingga era kelahiran organisasi tersebut. Tercatat FPI berdiri secara resmi pada tanggal 17 Agustus 1998 di Pondok Pesantren Al Umm, Cempaka Putih, Ciputat setelah sebelumnya ide pendiriannya digodog di petamburan yang sekarang menjadi markas FPI (Indra, 2016). Meskipun secara resmi didirikan pada tahun 1998, tetapi embrio dari FPI sendiri sudah ada sejak era Orde Baru, khususnya merujuk pada aktivitas dakwah Rizieq Shihab. Shihab sendiri bersal dari keluarga terpandang, yakni anak dari Sayyid Husein. Husein sendiri merupakan salah satu keturunan Arab-Hadrami yang cukup terkenal di masanya karena berhasil 
membentuk Gerakan Panda Arab. Sebuah gerakan kepanduan bagi masyarakat keturuan Arab di Indonesia (Wilson, 2015: 166). Dari latar belakang kepanduan inilah yang sekiranya dapat menjelaskan bagaimana Shihab mewarisi cara untuk mengorganisasikan sebuah kelompok yang cukup solid dan tangguh dalam aktivitas fisiknya. Secara anggota kepanduan sudah dibekali dengan berbagai pelatihan yang membuat fisik dan mental mereka lebih "kokoh" dibandingkan masyarakat kebanyakan.

Tentunya selain mewariskan cara mengorganisasikan sebuah gerakan, posisinya sebagai anak dari Sayyid Husein yang diyakini merupakan bagian dari garis keturunan Nabi Muhammad maka memberi ruang bagi Shihab untuk terjun ke dalam dunia dakwah. Tercatat setelah selesai menempuh pendidikan keagamaan, termasuk mengenyam pendidikan di Saudi Arabia, Shihab menjadi pengajar di maddarah (pesantren) kalangan keturunan Hadrami di bawah payung Jamiat Khair (Council, 2014). Dapat dikatakan persentuhannya dengan Jamiat Khairinilah yang natinya memberi jalan bagi Shihab untuk berkolaborasi dengan sejumlah Habib lain untuk mendirikan FPI (Efendi, 2010: 63; Zulkifli, 201318). ${ }^{17}$

Selama Orde Baru Shihab sendiri sudah dikenal dengan ideanya yang khas yakni melancarkan kritik terhadap pemerintah Orde Baru. Bagi Shihab pemerintah Orde Baru telah melakukan berbagai aktivitas kemaksiatan dan kemungkaran yang dilarang dalam perspektif Islam. Hal yang sama juga didakwahkan oleh sejumlah Habib dan kyai yang nantinya menjadi bagian dari elit FPI seperti Habib Idrus Jamalullail, KH Fathoni, KH Misbahul Anam dan K.H. Cecep Bustomi. Bahkan tercatat Habib Idrus dan K.H. Cecep sempat ditangkap oleh pemerintah Orde Baru karena kritikan tajam mereka terhadap pemerintah soal isu moralitas tersebut (Indra, 2016).

Tumbangnya Orde Baru membuat Shihab dan sejumlah Habib dan Kyai yang dikenal dengan ketegasannya tersebut berinisatif untuk mendirikan sebuah organisasi yang dapat mewujudkan citacita mereka dalam "membersihkan" Indonesia dari berbagai "kubangan" kemaksiatan dan problem moralitas lainnya. Keputusan ini menurut telaah Zastrow tidak dapat dilepaskan dari konteks reformasi itu sendiri yang melahirkan realitas baru yang berbeda dengan Orde Baru. Disatu sisi keruntuhan Soeharto tentu membawa angin segar bagi kalangan pendakwah tersebut untuk lebih menggencarkan dakwahnya tanpa takut untuk "diciduk" negara. Akan tetapi di satu sisi kebebasan pasca Orde baru tersebut juga membawa masalah tersendiri bagia Shihab dan sejumlah rekannya tersebut. Berbagai tindak kemaksiatan seperti praktik perjudian, narkoba, minuman keras, dan tempat-tempat kemaksiatan secara terbuka -sebagai imbas dari kebebasan tersebut- tentunya membuat Shihab dan rekannya gerah dengan perkembangan tersebut (Al-Zastrouw, 2006: 89). Sehingga para kyai dan Habib tersebut beranggapan menjadi sebuah kemestian jika mereka sendiri yang "turun tangan" guna "membantu pemerintah" untuk melawan berbagai bentuk kemaksiatan tersebut (Al-Zastrouw, 2006).

Dari temuan Al-Zastrouw (2006) di atas terlihat jelas adanya perubahan paradigma yang terjadi di kalangan para pendiri FPI. Jika di masa Orde Baru mereka mengkritik negara yang membiarkan berbagai tindak kemaksiatan merajalela. Namun, melemahnya negara itulah yang membuat mereka berinisiatif "membantu negara" dengan turun masuk ke ranah publik untuk menegakkan "order" 
dengan kekuatan tangan mereka sendiri. Jika menggunakan perspektif Islam tentang amar ma'ruf nahi munkar, paradigma FPI telah bertrasfromasi dari penggunaan lisan (nasehat) menjadi tangan (dengan kekuatan) (Luhur, 2017). ${ }^{18}$

Pada konteks amar maruf dalam dokumen tersebut dinyatakan bahwa FPI akan mengambil langkah persuasif (dengan lisan) akan tetapi dalam konteks nahi munkar justru aspek koersif (dengan tangan) yang menjadi prioritas FPI. Sementara jika kekuatan tangan tersebut tidak bisa dilakukan barulah FPI akan menggunakan lisan dan dengan hati (mengingkari tindakan mungkar) tersebut (Al-Zastrouw, 2006: 91). Tepat jika julukan FPI sebagai kelompok vigilante karena paradigma mereka memang mengacu pada konsepsi main hakim sendiri -yang sejatinya bertentangan dengan konsep nahi mungkar yang ortodox dalam Islam-. Misal, memiliki kegiatan "rutin" melawan berbagai tindakan yang dipandang tidak sesuai dengan aturan Islam (Kahin, 2015) yakni, melakukan aksi sweeping terhadap warung yang berjualan di sang hari di bulan ramadhan. Setelah memahami idea semacam apa yang dianut dan diperjuangkan FPI marilah kita masuk ke dalam analisa mengapa dengan idea yang "agresif” tersebut FPI dapat "menangsek masuk" ke ruang publik dan memaksakan nilai yang dianutnya dengan sokongan kekuatan fisik yang jelas bertentangan dengan ide multikulturalisme yang percaya bahwa penetrasi nilai dalam ruang publik harus dilakukan secara dialogis bukannya dengan aksi kekerasan atau koersif (Sutrisno, 2010). ${ }^{19}$

Sejarah mencatat, aksi koersif perdana FPI di ruang publik adalah melalui payung Pamswakarsa. Pamswakarsa sendiri adalah pasukan sipil pengaman jamannya sidang MPR dari potensi penolakan sidang tersebut dari koalisi Pelangi dengan tokoh utamanya Megawati. Sejalan dengan Hafner, Lee juga menyimpulkan adanya "ruang" yang "dibuka lebar" oleh polisi dan militer di bawah Wiranto dan Nugroho Jayusman sebagai aktor penting dibalik tampilnya FPI di ranah publik dengan aksi koersifnya. Lee bahkan menyebut sejumlah nama lain yang dianggap berjasa membesarkan FPI saat itu seperti Djaja Suparman (gubernur Jakarta), Mochsin Mochtar (suami dari puteri Habibie) dan Fuad Bawazir (Dirjen Pajak era Soeharto) sebagai penyandang dana FPI (Beittinger-Lee, 2009: 1990).

Massa FPI yang bergabung dalam Pamswakarsa dapat dikatakan juga membentuk kaedah perjuangan mereka. Dimana sebagaimana yang diungkap Sidel di kalangan FPI diwacanakan bahwa aksi kekerasan nyatanya berbuah pada kesuksesan penyelenggaraan sidang MPR (Sidel, 2006). Nampaknya logika yang ingin dibangun dengan narasi semacam itu adalah demi sebuah tujuan "mulia" (misal sidang MPR bisa disebut sebagai wujud demokrasi) maka cara untuk mencapai tujuan"mulia" tersebut menjadi sah, termasuk dalam hal ini adalah cara-cara non dialogis, koersif, dan kekerasan. Kaedah inilah yang nampaknya dipegangi FPI hingga saat ini dimana aksi mereka yang "keras" itu tidaklah mengapa untuk menggapai tujuan "mulia" mereka yakni Indonesia yang bebas dari berbagai perilaku imoral. Sebuah kaedah yang lagi-lagi bertentangan dengan logika multikulturalisme yang mensyaratkan cara-cara dialogis untuk memasukkan satu nilai dalam ruang publik.

Sebuah simpulan penting yang dapat ditarik dari penjelasan di atas -terkhusus terkait dengan pembahasan kita yakni multikulturalisme ialah adanya "perselingkuhan" antara negara dan FPI yang 
memungkinkan idea FPI yakni amar maruf nahi munkar secra koersif dapat "merangsek masuk" ke ruang publik. Jika kembali merujuk pada ide floating state dimana negara tidak mendengarkan kehendak warga kecuali kehendaknya sendiri, pelibatan kelompok masyarakat sipil atau bahkan kelompok viligante sekalipun dalam ruang publik yang sifatnya dominatif sangat dimungkinkan demi menjaga kepentingan negara. Demi survivalitas tersebut tidak peduli negara harus merangkul kelompok vigilante macam FPI bahkan mengizinkan mereka untuk berbuat kekerasan demi terjaganya kepentingan mereka. Terlihat jelas alphanya negara yang netral dan transendental disini memungkinkan dominasi ruang publik oleh kelompok tertentu dengan cara kekerasan. Jika kondisi semacam ini yang terjadi maka tidak bisa diharapkan penegakan multukulturalisme akan berjalan dengan baik dalam konteks Indonesia.

Pernyataan Sidel (2006) maupun Hefner (2012), FPI tidaklah menghilang pasca Pamswakarsa usai menjaga sidang MPR. Rentetan aksi FPI di ruang publik berbasis aksi koersif sedang menunjukkan bahwa organisasi tersebut terus berkembang dari waktu ke waktu namun tetap menerapkan paradigma "keras" mereka pada saat yang bersamaan. Tentunya kekuatan mereka sekali lagi tidak bisa terjelaskan tanpa melihat adanya problem pada negara dimana ide negara netral dan transendental tidak diterapkan misal pada tahun 1999 masih ditandai dengan kepemimpinan rezim Habibie dan Wiranto yang pro FPI.

Perkembangan FPI dan aksinya yang semakin masif di era reformasi dan otonomi daerah juga dapat dijelaskan dengan problem pada negara dimana ide negara netral dan transendental tidak diterapkan. Perlu dipahami bahwa dengan adanya otonomi daerah maka independensi daerah akan perintah pusat semakin besar. Pada konteks inilah ruang gerak FPI bisa semakin meluas karena ia dapat menjalin relasi yang lebih intens dengan aparat keamanan setempat atau elit politik yang memegang kuasa formal di sana. Ambil contoh aparat kepolisian misalnya, berdasar pengakuan dari Ustadz Komarudin -yang menjabat sebagai elit FPI di Yogyakarta- justru menegaskan adanya relasi yang terus terjadi antara pihaknya dengan kepolisian. Bahkan ia mengklaim FPI justru membantu kerja-kerja institusi kepolisian dalam memberantas kejahatan, termasuk kemaksiatan. Maka tidak heran dalam upaya "mengelola konflik di masyarakat" hingga "mencari solusi atas permasalahan" tersebut FPI tidak canggung untuk terus berkomunikasi pihak kepolisian (wawancara penulis, 25 Juli 2013). Tidak heran jika muncul "guyonan" yang menegaskan bahwa FPI kebal dengan hukum, karena tidak ada satu pun kasus yang melibatkan FPI diperpanjang hingga meja pengadilan. Semua pasti berakhir dengan "perdamaian" dan "kesepakatan".

Bahkan jika merujuk pada perkembangan politik kontemporer di tingkat nasional rezim Jokowi menegaskan akan mengikutsertakan sejumlah ormas Islam -termasuk FPI- untuk memberinya masukan dalam membuat nawacita jilid II (CNN Indonesia, 2018). Perkembangan ini tentunya semakin menegaskan bahwa pendekatan legal formal tersebut akan semakin sulit untuk bekerja jika di sisi lain eksekutor UU Ormas tersebut menampilkan sikap "lunak" pada FPI. 
Satu hal yang perlu disampaikan juga disini bahwa FPI tidak hanya melakukan "perselingkuhan" dengan negara saja. Perkembangan terkini menunjukkan bahwa FPI juga sedang berupaya masuk ke dalam tubuh negara. Hal ini misalnya ditegaskan ustadz Komarudin bahwa anak ketua umum FPI DIY -bernama Haji Bambang- yakni Dara Ayu Suharto maju sebagai caleg dari Partai Gerindra di bursa persaingan legislatif tingkat Kabupaten. Dengan sistem komando yang dimilikinya, FPI mengeluarkan maklumat (fatwa) bahwa seyogyanya anggota FPI memberikan suara pada kalangan yang dinilai mampu memperjuangkan visi dan misi FPI (CNN Indonesia, 2018). Tentu saja fatwa semacam ini memiliki makna implisit pula untuk mengarahkan dukungan FPI pada caleg semacam Dara Ayu Suharto.

Satu hal yang bisa ditarik dari kasus Dara Ayu Suharto tersebut ialah FPI ingin menjadi bagaian dari negara itu sendiri dan pada akhirnya menentukan jalannya negara. Jika kembali pada perspektif struktural fungsional tentunya menjadi hal yang membahayakan sebuah sistem ketika komponennya justru bertindak berkebalikan dari apa yang dimandatkan oleh sistem Dengan kata lain konsepsi negara netral dan transendental semakin tergerus dengan sendirinya.

\section{Penutup}

Berdasarkan lensa struktural-fungsional, studi ini menunjukkan bahwa multikulturalisme layaknya sebuah sistem yang hanya dapat bekerja dengan baik jika komponen di dalamnya juga mampu menopang sistem tersebut. Dua komponen penting yang disinggung dalam studi ini adalah neutral and transendental state dan sense of public yang kuat. Eksistensi neutral and transendental state menjadi penting untuk memastikan negara berdiri di atas semua pihak dan tidak mengistimewakan satu entitas kulural di atas kultur lainnya. Kehadiran neutral and transendental state juga penting untuk memastikan negara mampu menjaga order, yakni keberagaman- dengan instrumen yang dimilikinya termasuk aparat keamanan. Begitu pula dengan sense of public yang kuat sehingga masyarakat dapat menahan diri untuk melakukan berbagai aktivitas yang sifatnya dominatif dalam ruang publik. Telaaah pada studi ini menunjukkan bahwa dua komponen penting tersebut alpa dalam konteks Indonesia. Terkonfirmasi melalui sepak terjang FPI di Indonesia. Pemerintah -baik di tingkat pusat maupun lokal- gagal memposisikan diri untuk menjadi entitas yang netral dan transendental sehingga memungkinkan FPI untuk terus melakukan aneksasinya atas ruang publik.

Selama ini, paradigma yang berkembang lebih berbasiskan pada teksbook saja, yang memandang bahwa hanya dengan modal Undang-undang yang tegas dapat memastikan multikulturalisme bekerja. Memang benar, hal tersebut bisa berjalan di sejumlah negara Barat. Namun yang dilupakan oleh banyak pihak di Indonesia adalah teksbook tersebut hadir dalam konteks yang spesifik, yakni negara yang sudah memiliki infrastruktur dalam penerapan kebijakan legal formal tersebut, yakni sense of public dan neutral and transendental state. Sementara di Indonesia, masih memiliki kendala pada hal tersebut. Tentunya artikel ini tidak berpretensi untuk menyatakan bahwa multikulturalisme telah mati dalam konteks Indonesia. Akan tetapi, sikap pesimis yang menjadi spirit artikel ini adalah upaya untuk mengajak para akademisi dan semua pihak untuk berfikir secara kontekstual untuk melihat 
problema yang terjadi. Tidak hanya terlena dengan cara yang instan, tetapi pada hakikatnya tidak menyelesaikan masalah.

\section{Ucapan Terima Kasih}

Terima kasih kepada para responden yang telah berkenan memberikan informasi dan berdiskusi dalam upaya penyelesaian riset. Tulisan ini juga merupakan pengembangan dari naskah yang telah dipresentasikan dalam Workshop on Power, Conflict, \& Democracy 2018, Reflection on 20 Years 'Reformasi in Indonesia', Yogyakarta, 26-28 September 2018.

\section{Pendanaan}

Artikel ini didanai secara swadaya oleh penulis.

\section{Catatan}

1 Klasifikasi paham keagamaan kaum Muslim di Indonesia sebagai "mainstream” dan "non mainstream" ini dipakai oleh sejumlah akademisi Indonesia maupun Barat misalnya oleh As'ad Said Ali, Azyumardi Azra, dan Martin Van Bruinessen.

2 Seringkali istilah Islam radikal, Islam fundamentalis, Islam non-mainstream, Islam transnasional dipertukarkan untuk menyebut entitas yang sama oleh berbagai akademisi Indonesia dan Barat. Satu poin penting dari pendefinisian ini adalah untuk membedakannya dengan varian lain yang sering disebut Islam Indonesia, Islam moderat, Islam Mainstream yang disematkan pada NU dan Muhammadiyah yang dianggap para akademisi ini lebih mengayomi dibandingkan dengan varian sebelumnya yang disinonimkan dengan kekerasan, bahkan muncul istilah "Islam ramah" versus "Islam marah". Dalam studi ini, penulis lebih memilih menggunakan istilah Islam radikal, walaupun dengan makna yang sama dengan istilah lainnya yang dipakai para akademisi lain.

3 Misalnya ormas keagamaan NU, MUI, dan sejumlah akademisi seperti Azyumardi Azra. Jokowi sendiri dalam pidatonya di hadapan umat Buddha dalam acara Rapat Kerja Nasional 2017 Perwakilan Umat Buddha Indonesia di JIExpo 2017 menegaskan bahwa banyak kalangan yang mendukung Perppu tersebut, termasuk dukungan parpol di DPR.

4 Amin Mudzakkir dan Imdadun Rahmat misalnya meruakan contoh akademisi dengan sangat optimis menyetujui UU ormas yang dianggapnya dengan berbekal UU tersebut pemerintah dapat menangani radikalisme dan kasus intoleransi dengan cepat.

5 Faktanya pasca HTI tidak ada ormas radikal lain yang dibubarkan (misalnya FPI). Padahal jika diperbadingkan dengan perspektif multikulturalisme eksistensi FPI lebih "berbahaya" daripada HTI karena dikenal mengedepankan aksi kekerasan (fisik) bukan hanya "perang ide".

6 Faktanya di lapangan, misalnya, dapat ditemukan buletin Jum’at HTI Al Islam hanya berganti format dan nama saja menjadi buletin Kaffah, namun dengan konten yang sama 
7 Seperti pernyataan Said Aqil Siradj, Ketua PBNU, yang menyatakan akan "merangkul” mantan anggota HTI dengan mengajak mereka bergabung dengan NU namun setelahpara mantan HTI tersebut "disadarkan" dari ideologi ala HTI tersebut

8 Sebagai contoh di negara Eropa seperti Inggris ide yang "kontroversial” dalam kultur mereka juga dibiarkan untuk berkembang dan mengadakan berbagai aktivitas terbuka termasuk kalangan yang mengusung ide untuk mengubah negara Inggris menjadi bagian dari Kekhalifahan global. Tercatat di tahun 2016 mialnya lebih dari 1000 orang berkumpul di jalanan London menyerukan ide Khilafah global tersebut. Akan tetapi tidak ada penahanan terhadap aksi mereka karena kelompok tersbeut melakukan aksi secara damai dan lebih mengedepankan dialog rasional. Hal ini meunjukkan bahwa dalam perspektif multikulturalisme aksi semacam itu masih dalam "batas toleransi" karena tidak menggunakan aksi kekerasan untuk memperjuangkan pahamnya sebagaimana kalangan ISIS, AL Qaeda atau FPI di Indonesia

9 Istilah "texs book thinking" (berfikir ala teksbook) seringkali dinisbatkan pada Soekarno yang dalam sejumlah pidato politiknya menggunakan istilah ini. Soekarno sendiri menggunakan istilah ini dalam konteks revolusi Indonesia. Bagi Soekrno tidak ada revolusi (maksudnya dalam hal mengisi kemerdekaan) yang merujuk pada buku teks universal. Setiap revolusi pasti berbasis pada karakteristik lokalitas yang khas dan tidak bisa diterapkan secara sama $100 \%$ di wilayah lainnya. Soekarno sendiri berupaya membangun kesadaran bahwa dalam konteks Indondesia, revolusi yang "khas" itlah yang perlu untuk dikembangkan tidak hanya "silau" dengan "teks" tentang revolusi lain yang terjadi di berbagai belahan dunia.

10 Dari logika inilah maka bisa kita maklumi mengapa dalam konteks negara Inggris misalnya mengizinkan digelarnya demonstrasi pro Khalifah ala Hizbut Tahrir misalnya. Alasannya membatasi idea seseorang/kelompok kebudayaan tertentu adalah bentuk monokultur itu sendiri yang secara prinsipil bertentangan dengan prinsip multikulturalisme. Akan tetapi jelas para demonstran itu sendiri memiliki sense of belonging tersendiri terhadap political community negara bangsa Inggris, dimana mereka tidak anarkis dengan merusak jalan misalnya, berdemo di jalur yang sudah dinegosiasikan dengan aparat keamanan, dan tidak melakukan penyerangan terhadap pihak lain yang sependapat dengan mereka misalnya.

11 Para sosiolog membuat sejumlah definisi khas mereka untuk menggambarkan kesatuan kerjasama antara bagain masyarakat ini, seperti Durkeim yang menyebutnya solidaritas (solidarity) atau Brown yang menyebutnya harmoni (harmony) atau konsistensi (consistency). Akan tetapi dari istilah khas tersebut seuamnya merujuk pada makna yang sama.

12 Logikanya dalam dunia tanaman antara tamanan yang berakar tunggang dan serabut saja lebih rentan tercerabut yang berakar serabut. Apalgi tidak punya akar. Sehingga dalam konsepsi Lay tersebut sejatinya negara Indoensia modern ini posisinya bagai telur diujung tanduk karena tidak punya fondasi kokoh.

13 Memerintah memiliki istilah yang lebih dominatif dibandingkan degan menjaga. Karena asumsinya ada yang memerintah (yakni negara) dan ada yang diperintah (yakni rakyat). Secara tidak sadar konotasi tersebut mengukuhkan relasi timpang (subordinasi) antara negara terhadap 
rakyatnya, dimana tugas dari yang diperintah adalah melaksanakan apa yang diperintahkan kepadanya bukan membangkang.

14 Sebut saja Donald K Emerson yang mengumpulkan sejumlah analisa dari akademisi Barat kontra Anderson yang menyebutkan bahwa pembacaan negara sebagai sebuah entitas tunggal tidaklah tepat. Menulkil penjelasan Willaim Lidde misalnya ditemukan fakta bahwa di dalam tubuh militer sekalipun - pada masa Orde Baru militer adalah backing Soeharto- ternyata tidaklah satu suara. Ada berbagai fraksi di dalamnya dengan kepentingan berbeda.

15 Misalnya dalam konteks kebijakan BPJS yang dicanangkan pemerintah pusat. Tercatat sejumlah daerah yang tidak mendukung bahkan seperti Kabupaten Gowa justru menggugat program tersebut. Hal ini menunjukkan tidak sinkronnya logika penyediaan kesehatan antara pusat dan daerah.

16 Misalnya kasus "Cicak versus Buaya” dimana terjadi perseteruan antara KPK dan polisi padahal kedua lembaga tersebut seharusnya bersinergi dalam memerangi tindak pidana korupsi.

17 Jamiat Khair jika merujuk pada dikotomi modernis-tradisionalis ala Deliar Noer maka organisasi ini tergolong ke dalam kubu tradisionalis yang lekat dengat kultur NU sperti tahlilan, yasinan, taqlid, dan anti terhadap ide purifikasi ala Wahhabi. Dimasa Jami'at Khair, organisasi ini memposiskan Al Irsyad yang tergolong dalam kubu modernis -walau anggotanya juga berasal dari kalangan Hadrami- sebagai musuh besarnya. Tidak heran jika nantinya kultur tradisionalis ini dapat dilihat pula dalam organisasi FPI bahkan dalam perkara mahajiah (paradigmatik) nya.

18 Dalam konsepsi Islam amar ma’ruf nahi mungkar menggunakan tangan (kekuatan paksa) sejatinya hanya dapat dilakukan oleh negara, bukan oleh individu atau kelompok tertentu. Hal ini mengacu pada anarkisme jika semua pihak dapat mengkalim bahwa tindakan mereka merupakan ikhiyar untuk menegakkan hukum. Namun nampaknya dalam konteks Indonesia tidak hanya FPI secara khusus namun masyarakat Indoensia secara umum juga seringkali melakukan amar maruf nahi mungkar ini dengan tangannya sendiri. Misal menghakimi pencuri atau penjambret yang berhasil mereka tangkap. Tak jarang berbagai siksaan hingga pembunuhan terhadap kriminal tersebut mereka lakukan sebagai abgaian dari pengadilan jalanan ala mereka.

19 Pentingnya dialog dalam mengintrodusir nilai ke dalam ruang publik ini mengacu pada ide Habermas tentang ruang publik

\section{Daftar Pustaka}

Ahmad, R. (2017). Perppu No 2 Tahun 2017 Ancaman Demokrasi? Diakses pada 2 Mei 2019, dari https://mediaindonesia.com/read/detail/113186-perppu-no-2-tahun-2017-ancaman-demokrasi Al-Zastrouw, N. (2006). Gerakan Islam Simbolik: Politik Kepentingan FPI. Yogyakarta: LKiS.

Ali, S. A. (2011). Islam non-Mainstream. Diakses pada 5 Agustus 2018, dari https://www.nu.or.id/ post/read/32202/islam-non-mainstream

Anderson, B. R. (1983). Old state, new society: Indonesia's new order in comparative historical perspective. The Journal of Asian Studies, 42(3), 477-496. https://doi.org/10.2307/2055514 
Azra, A. (2013). Distinguishing Indonesian Islam: Some Lessons to Learn. In J. Burhanudin \& K. van Dijk (Eds.), Islam in Indonesia: Contrasting Images and Interpretations. Amsterdam: Amsterdam University Press.

Beittinger-Lee, V. (2009). (Un) Civil Society and Political Change in Indonesia A Contested Arena. Abingdon: Routledge. https://doi.org/10.4324/9780203868799

Bekker, S., \& Leildé, A. (2003). Is multiculturalism a workable policy in South Africa. International Journal on Multicultural Societies, 5(2), 121-136. Diunduh dari http://www.simonbekker.com/ simonsdocs/IJMS5_2.multiculturalism ppr.pdf

Bolo, A. D. (2006). Man of Dialogue. In F. Borgias, A. D. Bolo, \& B. A. Sidharta (Eds.), Prof. Dr. Mgr. N.J.C. Geise, OFM: Juragan Visioner. Yogyakarta: Kanisius.

Bruinessen, M. van. (2013). Overview of Muslim Organizations, Associations, and Movements in Indonesia. In M. van Bruinessen (Ed.), Contemporary Developments in Indonesian Islam: Explaining the "conservative turn." Singapore: ISEAS.

CNN Indonesia. (2018). Koalisi Jokowi Minta Masukan FPI dan Ormas Susun Visi-Misi. Diakses pada 14 Mei 2018, dari https://www.cnnindonesia.com/nasional/20180807074011-32-320090/ koalisi-jokowi-minta-masukan-fpi-dan-ormas-susun-visi-misi

Council, A. F. (2014). The World Almanac of Islamism : 2014. Lanham: Rowman \& Littlefield.

Efendi, D. (2010). Pembaharuan Tanpa Membongkar Tradisi: Wacana Keagamaan di Kalangan generasi Muda NU Masa Kepemimpinan Gus Dur. Jakarta: Kompas.

Elson, R. (2001). Brief Reflection on Indonesian Political History. In G. J. Lloyd \& S. L. Smith (Eds.), Indonesia Today: Challenges of History. Singapore: ISEAS.

Emmerson, D. K. (1983). Understanding the New Order: Bureaucratic Pluralism in Indonesia. Asian Survey, 23(11), 1220-1240. https://doi.org/DOI: 10.2307/2644374

Erdianto, K. (2017). Perppu Ormas, Definisi Paham Bertentangan dengan Pancasila Diperluas. Diakses pada 8 Mei 2018, dari https://nasional.kompas.com/read/2017/07/12/14001971/perppu-ormasdefinisi-paham-bertentangan-dengan-pancasila-diperluas

Erwanti, M. oktavia. (2018). Koalisi Jokowi akan Minta Masukan Ormas Keagamaan, Termasuk FPI. Diakses pada 10 Agustus 2018, dari https://news.detik.com/berita/4153225/koalisi-jokowi-akanminta-masukan-ormas-keagamaan-termasuk-fpi

Express. (2016). 1000 Muslims close London streets to chant Allahu Akbar and demand Islamic caliphate. Diakses pada 5 Agustus 2018, dari https://www.express.co.uk/news/world/743825/1000Muslims-close-London-streets-chant-Allahu-Akbar-demand-Islamic-caliphate

Fortier, A.-M. (2008). Multicultural Horizons Diversity and the Limits of the Civil Nation. Abingdon: Routledge.

Goh, D. P. (2016). The Plural Society and Multiculturalism in Malaysia and Singapore. Abingdon: Routledge. Diunduh dari https://www.taylorfrancis.com/books/e/9781315596228/chapte rs/10.4324/9781315596228-14 
Haris, S. (2006). Membangun format baru otonomi daerah. Jakarta: Yayasan Obor Indonesia.

Harris, M. (2001). The Rise of Anthropological Theory: A History of Theories of Culture. Lanham: AltaMira Press.

Hefner, R. W. (2012). Islamic Radicalism in Democratizing Indonesia. In S. Akbarzadeh (Ed.), Routledge Handbook of Political Islam. Abingdon: Routledge.

Heng. (2017). Opinion | Heng on Indonesia’s Decree to Ban Radical Groups. R Diakses pada 5 Agustus 2018, dari https://www.nytimes.com/2017/07/16/opinion/heng-on-indonesias-decree-to-banradical-groups.html

Ibrahim, G. M. (2017). Dukung Perppu Ormas, Azyumardi: Ini soal Eksistensi Bangsa. Diakses pada 8 Mei 2018, dari https://news.detik.com/berita/d-3689610/dukung-perppu-ormas-azyumardiini-soal-eksistensi-bangsa

Ichwan, M. N. (2013). Toward A Puritanical Moderate Islam: The Majelis Ulama Indonesia and the Politics of Religious Orthodoxy. In M. van Bruinessen (Ed.), Contemporary Developments in Indonesian Islam: Explaining the "conservative turn." Singapore: ISEAS.

Indra, P. A. (2016). FPI dalam Lintasan Sejarah. Diakses pada 5 Agustus 2018, dari https://tirto.id/ fpi-dalam-lintasan-sejarah-b1NT

Jawa Pos. (2016). Banyak Daerah Tolak BPJS, Ini Sebabnya. Diakses pada 5 Agustus 2018, dari https:// www.jawapos.com/nasional/humaniora/08/05/2016/banyak-daerah-tolak-bpjs-ini-sebabnya-

Jordan, R. (2017). Istana: Tak Terima Dibubarkan, Ormas Bisa Gugat Pemerintah ke PTUN. Diakses pada 5 Agustus 2018, dari https://news.detik.com/berita/d-3562010/istana-tak-terimadibubarkan-ormas-bisa-gugat-pemerintah-ke-ptun

Jupp, J. (2011). Multiculturalism and Integration A Harmonious Relationship. Canberra: ANU E Press. Kahin, A. . (2015). Historical Dictionary of Indonesia. Lanham: Rowman \& Littlefield.

Kamran, T. (2007). Islam, Urdu and Hindu as the Other: Instruments of Cultural Homogeneity in Pakistan. In B. Chandra \& S. Mahajan (Eds.), Composite Culture in a Multicultural Society (pp. 93-122). New Dhelhi.

Kuwado, Fabian Januaris. (2017). Perppu Ormas Disahkan, Jokowi Nilai Banyak yang Dukung Jaga Pancasila. Diakses 5 Agustus 2018, dari https://nasional.kompas.com/read/2017/10/26/10334761/ perppu-ormas-disahkan-jokowi-nilai-banyak-yang-dukung-jaga-pancasila

Kuwado, Fabian Januarius. (2017). Perppu Ormas Disahkan, Jokowi Nilai Banyak yang Dukung Jaga Pancasila. Diakses pada 8 Agustus 2018, dari https://nasional.kompas.com/ read/2017/10/26/10334761/perppu-ormas-disahkan-jokowi-nilai-banyak-yang-dukung-jagapancasila

Lane, R. (1976). Criminal Violence in America: The First Hundred Years. The Annals of the American Academy of Political and Social Science, 423, 1-13. Diunduh dari https://www.jstor. org/stable/1041418 
Lay, C. (2012). Democratic Transition in Local Indonesia: An Overview of Ten Years Democracy. Jurnal Ilmu Sosial Dan Ilmu Politik, 15(3). https://doi.org/10.22146/jsp.10915

Leilde, S. B. (2003). Is Multiculturalism a Workable Policy in South Africa? International Journal on Multicultural Societies (IJMS), 5(22). Diunduh dari http://simonbekker.com/simonsdocs/ IJMS5_2.multiculturalism ppr.pdf

Luhur, A. B. (2017). Cara Mengamalkan Hadits Amar Ma'ruf Nahi Munkar. Diakses pada 2018, dari https://islam.nu.or.id/post/read/84670/cara-mengamalkan-hadits-amar-maruf-nahi-munkar

Massier, A. (2008). The Voice of the Law in Transition: Indonesian Jurists and Their Languages, 19152000. Leiden: KITLV Press.

Meien, J. v. (2004). The Multiculturalism Vs. Integration Debate in Great Britain. Norderstedt Germany: GRIN Verlag.

Movanita, ambaranie N. K. (2017). Ada Perppu, Polri Merasa Lebih Mudah Tindak Anggota Ormas Bermasalah. Diakses pada 5 Agustus 2018, dari https://nasional.kompas.com/ $\mathrm{read} / 2017 / 07 / 13 / 19150341 / a d a-p e r p p u-p o l r i-m e r a s a-l e b i h-m u d a h-t i n d a k-a n g g o t a-o r m a s-$ bermasalah

Newman, D. M. (2010). Sociology: Exploring the Architecture of Everyday Life. California: Pine Forge Press.

Nordholt, H. S., \& Klinken, G. Van. (2007). Renegotiating boundaries: local politics in post-Suharto Indonesia. Leiden: KITLV Press.

NU Online. (2018). Buletin Kaffah Diduga Milik HTI Masih Menyebar di Jombang. Diakses pada 5 Agustus 2018, dari https://www.nu.or.id/post/read/86255/buletin-kaffah-diduga-milik-htimasih-menyebar-di-jombang

Olofinjana, I. O. (2014). The Significance of Multicultural Churches in Britain: A Case Study of Crofton Park Baptist Church. In Churches, Blackness, and Contested Multiculturalism (pp. 75-85). New York: Palgrave Macmillan.

Parekh, B. (1999). What is Multicilturalism? In A symposium on democracy in culturally diverse societies. Diakses dari https://www.india-seminar.com/1999/484/484 parekh.htm

Prihatin, I. U., Mashabi, S., \& Mardani. (2017). Ketika Muhammadiyah dan NU berseberangan di Perppu Ormas. Diakses pada 5 Agustus 2018, dari https://www.merdeka.com/peristiwa/ketikamuhammadiyah-dan-nu-berseberangan-di-perppu-ormas.html

Putri, Z. A. (2017). Dukung Perppu Ormas, MUI: Pancasila Dasar Negara Final. Diakses pada 8 Mei 2018, dari https://news.detik.com/berita/3679458/dukung-perppu-ormas-mui-pancasila-dasarnegara-final

Qurtuby, S. A. (2017). Pro-Kontra Perppu No. 2 Tahun 2017. Diakses pada 10 Agustus 2019, dari https:/www.dw.com/id/pro-kontra-perppu-no-2-tahun-2017/a-39827177 
Rimawan, R. (2014). Bila Dibubarkan, FPI Akan Ganti Nama seperti ’Bukan Empat Mata. Diakses pada 5 Agugustus 2018, dari https://manado.tribunnews.com/2014/10/13/bila-dibubarkan-fpiakan-ganti-nama-seperti-bukan-empat-mata

Sahrasad, H. (2009). Centurygate: Refleksi Ekonomi-Politik Skandal Bank Century. Jakarta: Freedom Foundation, Yayasan Indonesia Baru \& LSIK.

Santoso, P. (2018). Lokalitas Sebagai Konteks untuk Berdemokrasi. In P. Santoso, L. N. Bayo, \& W. P. Samadhi (Eds.), Rezim Lokal di Indonesia: Memaknai Ulang Demokrasi Kita. Jakarta: Yayasan Obor Indonesia. Yogyakarta: Yayasan Obor Indonesia.

Sasongko, J. P. (2017). DPR Sahkan Perppu Ormas Jadi Undang-undang. Diakses pada 6 Maret 2018, dari https://www.cnnindonesia.com/nasional/20171024135314-32-250616/dpr-sahkan-perppuormas-jadi-undang-undang

Sidel, J. T. (2006). Riots, Pogroms, Jihad: Religious Violence in Indonesia. New York: Cornell University Press.

Silaen, V. (2013). Pemimpin atau Pengemis. Tabloid Reformata, 166, 6.

Sutrisno, M. (2010). Krisis Ruang Publik Kultural. In F. B. Hardiman (Ed.), Ruang Publik. Melacak Partisipasi Demokratis dari Polis Sampai Cyberspace. Yogyakarta: Kanisius.

Tempo.co. (2018). Kasus Korupsi Tahun 2017, ICW: Kerugian Negara Rp 6,5 Triliun. Diakses pada 21 April 2019, dari https://nasional.tempo.co/read/1062534/kasus-korupsi-tahun-2017-icwkerugian-negara-rp-65-triliun

Tribunnews.com. (2018). Bongkar Tenda Nikah Pakai Jalan Umum, Polisi: Gak Tahu Diri, Mau Hajatan Gak Bermodal. Diakses pada 20 Mei 2018, dari https://medan.tribunnews.com/2018/02/01/ bongkar-tenda-nikah-pakai-jalan-umum-polisi-gak-tahu-diri-mau-hajatan-gak-bermodal

Turmudi, E., \& Sihbudi, R. (Eds.). (2005). Islam dan radikalisme di Indonesia. Jakarta: LIPI Press.

Umam, F. (2015). Kala Beragama Tak Lagi Merdeka: Majelis Ulama Indonesia dalam Praksis Kebebasan Beragama. Jakarta: Kencana.

Wahab, A. J. (2014). Manajemen Konflik Keagamaan: Analisis Latar Konflik Keagamaan Aktual. Jakarta: PT. Elex Media Komputindo.

Widyantini, A. R. (2016). Globalisasi dan Radikalisme Islam. In M. Hisyam \& C. Pamungkas (Eds.), Indonesia, Globalisasi, dan Global Village. Jakarta: Yayasan Obor Indonesia.

Wilson, I. D. (2015). The Politics of Protection Rackets in Post-New Order Indonesia: Coercive Capital, Authority, and Street Politics. Abdingdon: Routledge.

Zulfikar, M. (2017). Dukung Perppu Ormas, Said Aqil Siradj Persilakan Mantan Anggota HTI Masuk NU. Diakses pada 8 Mei 2018, dari https://www.tribunnews.com/nasional/2017/10/21/dukungperppu-ormas-said-aqil-siradj-persilakan-mantan-anggota-hti-masuk-nu

Zulkifli. (2013). The Struggle of the Shi is in Indonesia. Canberra: ANU Press. 
Multikulturalisme Tanpa Fondasi: Limitasi Pendekatan Legal-Formal dalam Mewujudkan...

\section{Tentang Penulis}

Nuruddin Al Akbar mahasiswa doktoral Ilmu Politik Universitas Gadjah Mada, dan peneliti di Institute for Multiculturalism and Pluralism Studies, Yogyakarta, dengan area riset seputar gerakan Islam politik, budaya politik, studi keamanan dan kajian demokrasi.

Listiana Asworo adalah dosen Program Studi Ilmu Pemerintahan, Universitas Muhammadiyah Malang, dengan area riset seputar politik keamanan, gerakan sosial, dan kajian demokrasi. 